\title{
'The incineration of refuse is beautiful': Torquay and the introduction of municipal refuse destructors
}

\author{
J.F.M. CLARK* \\ Institute for Environmental History, University of St Andrews, St Katharine's \\ Lodge, St Andrews, Fife, KY16 9AL
}

\begin{abstract}
In the last decade of the nineteenth century, the English seaside and health resort of Torquay abandoned its old practice of municipal waste tipping and invested in a destructor, or incinerator. Technical, legal and financial considerations lay behind this decision. The ensuing protests against the operation of the destructor highlight the tensions between nascent technocrats and the affected residents. At a time when pollution was most often displaced or dispersed, topography conspired against the residents of Torquay, and challenged the accepted spatial and social relationships of waste.
\end{abstract}

Waste is fundamentally important to the study of environmental history because it encompasses 'nature, land, production, consumption, the past and the future'. ${ }^{1}$ By definition, waste forces the historian to confront value, temporality and the 'metabolism' of urban industrial capitalism. The urban context has recently attracted attention within the historiography of the environment. In his wide-ranging review of the current state of environmental history, J.R. McNeill contends that ' $[u]$ rban environmental history ... has become the most exciting frontier' in the USA. ${ }^{2}$ Despite D. Worster's exclusion of the built environment from his agroecological perspective, a number of historians pursued the relationships between urban environment, technology, pollution and sanitation throughout the 1980s and 1990s. ${ }^{3}$ Ironically, Worster's exclusion

* I gratefully acknowledge that research for this article was generously provided by an AHRC Centre Awards Scheme grant. Tim Cooper provided helpful assistance with research. Moreover, my argument has been enhanced through numerous lively discussions with him.

${ }^{1}$ H. Rogers, Gone Tomorrow: The Hidden Life of Garbage (New York and London, 2005), 3.

2 J.R. McNeill, 'Observations on the nature and culture of environmental history', History and Theory, Theme Issue, 42 (2003), 5-43 (16).

3 D. Worster, 'Transformations of the earth: toward an agroecological perspective in history', Journal of American History, 76 (1990), 1087-106; M. Melosi, 'Environmental crisis in the city: the relationship between industrialization and urban pollution', in M.V. Melosi (ed.), Pollution and Reform in American Cities, 1870-1930 (Austin and London, 1980), 3-31; C. Rosen and J. Tarr, 'The importance of an urban perspective in environmental history', Journal of 
of the built environment perpetuates a reification of 'the' environment: a nature somehow separate from the urban conurbations where just under half of the world's population now resides. ${ }^{4}$ More recent analyses of urban metabolism, and the ecological footprint, have bridged the rural/urban dichotomy. Waste flow and management play significant roles in these studies because unchecked waste generation can lead to ecosystem collapse. $^{5}$

B. Luckin has lamented the relative neglect of urban environmental history in Britain, the first industrial nation. He speculates that a 'refuse revolution' occurred in the late nineteenth and early twentieth centuries. ${ }^{6}$ The 'refuse revolution' was one facet of the extension of service industries: the nineteenth-century revolution in government and the birth of an increasingly technocratic government. ${ }^{7}$ Through a case study of Torquay, this article argues that 'destruction' (cremation or incineration) of municipal household waste embodied the 'refuse revolution' ${ }^{8}$ Destructors were large-scale municipal projects that were funded through loans from central government. They were grand technological solutions to the nuisance and public health threat of accumulating waste in urban industrial Britain. Most significantly, destructors marked the shift from a domestic culture of reuse and recycling to technocratic management of waste disposal. From their inception, incinerators were promoted as clean and efficient. By burning rubbish to generate electricity, waste-toenergy incinerator schemes seemed to offer a via media between reuse and disposal. The destructor embodied 'municipal modernity' because it promised improved public health through efficient management of waste. ${ }^{9}$ In the quest for efficient high temperature combustion from

Urban History, 20 (1994), 299-310; J. Hassan, Prospects for Economic and Environmental History (Manchester, 1995); and D. Schott, B. Luckin and G. Massard-Guilbaud (eds.), Resources of the City: Contributions to an Environmental History of Modern Europe (Aldershot, 2005).

${ }^{4}$ UNEP, Global Environment Outlook 3 (2002), xxiv.

${ }^{5}$ M. Wackernagel and W. Rees, Our Ecological Footprint: Reducing Human Impact on the Earth (Gabriola Island, BC, 1996), 8; A. Wolman, 'The metabolism of cities', Scientific American, 213 (Sep. 1965), 178-90; W. Cronon, Nature's Metropolis: Chicago and the Great West (New York and London, 1991); I. Douglas, R. Hodgson and N. Lawson, 'Industry, environment and health through 200 years in Manchester', Ecological Economics, 41 (2002), 235-55; and S. Barles, 'A metabolic approach to the city: nineteenth- and twentieth-century Paris', in Schott, Luckin and Massard-Guilbaud (eds.), Resources of the City, 28-47.

6 B. Luckin, 'Pollution in the city', in M. Daunton (ed.), The Cambridge Urban History of Britain, vol. III: 1840-1950 (Cambridge, 2000), 207-28.

7 R.M. Hartwell, 'The service revolution: the growth of services in modern economy', in C.M. Cipolla (ed.), The Fontana Economic History of Europe: The Industrial Revolution (London, 1973), 358-96; H. Perkin, The Rise of Professional Society: England since 1880 (London, 1989); E. Armstrong, M.C. Robinson and S.M. Hoy (eds.), History of Public Works in the United States 1776-1976 (Chicago, 1976).

8 By the end of the nineteenth century, municipal household waste was defined as 'waste material which has to be dealt with by the public authorities; it then consists of ash-bin rubbish from the houses, shops, and market refuse, road sweepings, and excremental matter'. See E.C.S. Moore, Sanitary Engineering (London, 1898), 529.

9 W.P. McGowan, 'American wasteland: a history of America's garbage industry, 1880-1989', Business and Economic History, 24 (1995), 155-63 (159). 
a heterogeneous fuel, the destructor literally fed the flames of postconsumption waste generation in a fully realized capitalist economy: the destructor's appetite facilitated a throwaway society. Ultimately, the destructor proved inefficient and, as its name implies, it left a strong legacy of disposal. Post-consumption waste became the accepted shadow of an ideology of progress that lay at the heart of modernity. ${ }^{10}$

Nevertheless, local opposition to destructors highlighted ambiguities surrounding nuisances, public health threats and air pollution in late nineteenth- and early twentieth-century Britain. Technocrats promoted the destructor as the most effective means of neutralizing the public health danger created by decaying rubbish. In the face of threatened legal action, local councils embraced 'purification through fire' as the most efficient way of removing the noisome nuisance of town refuse. The resultant smoke produced by destructors elicited complaints from local residents, who raised concerns for public health and threatened legal nuisance actions. Social and cultural contexts played significant roles in shaping the environmental history of waste in the late nineteenth and early twentieth centuries.

\section{Methods of rubbish disposal: 'shuffle and dodge'?}

Increased waste generation was one facet of the growth of an urban industrial society. At first, a number of different private and local strategies were devised to deal with urban waste flow. Historically, tipping has been one of the most popular methods of rubbish disposal in Britain. ${ }^{11}$ Often this meant that natural or human-generated depressions in the ground were filled, and then the rubbish was left to decay in the open air. Quarries and clay-pits were considered ideal sites, because they combined physical location - gaping holes - with some opportunity for reuse. Rubbish was often used in the brick-making process. After an initial sifting, the fine ashes were mixed with the bricks as part of the firing element, while the breeze or cinder was used as fuel for the kilns. The remainder was burnt and its residuum was used in road construction. ${ }^{12}$

Alternatively, coastal communities often perceived the sea as an ideal dumping ground, but tides had a nasty habit of returning waste to dry ground. New York had to reconsider the practice of dumping at sea after refuse and animal carcases found their way back to a stretch of beach between Coney Island and Far Rockaway. ${ }^{13}$ Similarly, Nice confronted

10 See J. Scanlan, On Garbage (London, 2005).

11 See J.C. Wylie, The Wastes of Civilization (London, 1959), 23; and M. Gandy, Recycling and the Politics of Urban Waste (London, 1994).

12 J.H. Maxwell, The Removal and Disposal of Town Refuse (London, 1898), 68; and W.F. Goodrich, The Economic Disposal of Town's Refuse (London, 1901), 6.

${ }^{13}$ Dumping of refuse at sea was a violation of the federal Marine Protection Act of 1888. See B. Miller, Fat of the Land: Garbage in New York, the Last Two Hundred Years (New York and London, 2000), 69. 
beached waste on its two principal promenades. In Britain, Liverpool used two Corporation steamers, the Alpha and Beta, to dump refuse at sea. Carrying loads of 330 tons and 400 tons, respectively, the steamers made the 24-mile journey to the Irish Sea four times per week. By the turn of the twentieth century, however, there were increasing complaints of refuse washing up on the Welsh coast, and fishermen complained that their trawling nets were being filled with tins and other rubbish. ${ }^{14}$ After offending UK and European neighbours, and interfering with the fishing industry, dumping at sea became an unacceptable waste disposal strategy.

Different localities valued their refuse in a variety of ways. Some communities engaged in utilization, separation and pulverization as part of a commitment to obtaining a marketable value from refuse. This permitted a management solution that retained some continuity with past practices of domestic reuse. These practices had, however, fallen from favour by the late nineteenth century. Social critics, such as H. Mayhew, had effectively rendered the dust-yard sifters the embodiment of moral impoverishment and contagion. ${ }^{15}$ City engineer D.J. Ross condemned the continuation of dust sorting by women in Lambeth in 1904:

[T] hese unfortunate creatures have worked from morning to night, surrounded with dust up to their waists, inhaling an atmosphere more or less polluted. The system, apart from the humanitarian aspect, was condemned from the point of sanitation, on the ground that all refuse should be destroyed or got rid of before the products of putrefaction can poison the atmosphere. ${ }^{16}$

Sanitary engineer W.F. Goodrich contended that the class of people found on tips were invariably those who are ill-nourished and habitually dirty... Residing... in the poorer and crowded parts of town it is only reasonable to expect that they are the very people to spread disease.' Stirring the glowing embers of an Enlightenment ideology, Goodrich asked: 'Is this state of things worthy of our sanitary progress at the dawn of the twentieth century?' Significantly, he contended that refuse sorting and utilization represented 'a policy of shuffle and dodge' because refuse had simply been displaced rather than disposed with any sort of finality. ${ }^{17}$ Similarly, the Municipal Journal questioned the monetary value of sorting, and rebuked the practice as the embodiment of the degradation of women and girls. 'Why', they asked, 'is not the whole of the refuse burned by the destructors provided?'18

Refuse utilization was not defended on the grounds of the intrinsic merits of reuse. Although the politics of progressivism in the United States,

${ }^{14}$ Maxwell, Removal and Disposal of Town Refuse, 71-3; and Goodrich, Economic Disposal of Town's Refuse, 16-17.

15 H. Mayhew, London Labour and London Poor (1851-52; repr. London, 1985), 230.

16 D.J. Ross quoted in 'Refuse disposal problems', Municipal Journal, 29 Apr. 1904, 346.

17 Goodrich, Economic Disposal of Town's Refuse, 8, 21.

18 'London's disgrace: women sorters in Lambeth', Municipal Journal, 9 Sep. 1904, 726. 
and to a lesser extent in Great Britain, had generated a commitment to conservation management of some natural resources, this did not generally extend to refuse. ${ }^{19}$ A pre-existent and successful trade in urban dung (animal and human) provided the economic incentive for the continuance of some form of refuse utilization. The sheer quantity of dung might be staggering in urban areas in an era dominated by horse transport, cowsheds, minor piggeries, middens and cesspits. A healthy city horse, for instance, produced over 20 pounds of manure and gallons of urine each day. ${ }^{20}$ For some municipalities, the management of refuse was principally the management of excrement, or excrement compounds, that their councils considered to be valuable commodities. ${ }^{21}$

Hailed by recent environmental historians as an example of nineteenthcentury sustainability, the use of town dung as agricultural fertilizer constituted one of the means of dealing with refuse. ${ }^{22}$ Throughout most of the nineteenth century, for example, the sale of town dung proved a profitable venture for the Corporation of Dundee, and rendered the Carse of Gowrie one of the most fertile fruit-growing areas in Scotland..$^{23}$ The introduction of drains, however, created separate waste streams in most urban centres, and began the decline in the dung trade. By the end of the nineteenth century, municipal waste contained: organic food discards and garden waste; rags, glass, crockery and metals; ash and breeze from coal fires; and street sweepings (animal dung and dirt). Ash was the single greatest constituent of household rubbish. Nascent nineteenth-century sanitary experts implored people to burn as much of their waste as possible in home fires. They especially promoted the destruction of putrescible food waste by fire. ${ }^{24}$

19 This did not, of course, preclude a concern for waste. G. Pinchot and G.P. Marsh promoted the reduction and reuse of post-production waste to conserve natural resources. They displayed less interest in post-consumption waste. See D.J. Zarin, 'Searching for pennies in piles of trash: municipal refuse utilization in the United States, 1870-1930', Environmental Review, 11 (1987), 207-22 (208-10). In addition, see: S.P. Hays, Conservation and the Gospel of Efficiency: The Progressive Conservation Movement, 1880-1920 (Pittsburg, 1959); and M.V. Melosi, Garbage in the Cities: Refuse, Reform and the Environment, 1880-1980 (College Station, TX, 1981), 32, 182, 189.

${ }^{20}$ Melosi, Garbage in the Cities, 24-5.

${ }^{21}$ See, for instance, W. King, 'How high is too high? Disposing of dung in seventeenth-century Prescot', Sixteenth Century Journal, 23 (1992), 442-57; and Wylie, Wastes of Civilization, 19-26.

22 J. Sheail, 'Town wastes, agricultural sustainability and Victorian sewage', Urban History, 23 (1996), 189-209; N. Goddard, '19th-century recycling: the Victorians and the agricultural utilization of sewage', History Today, 31 (1981), 32-6; and N. Goddard, "“A mine of wealth"? The Victorians and the agricultural value of sewage', Journal of Historical Geography, 22 (1996), 274-90.

23 Wylie, Wastes of Civilization, 51.

${ }^{24}$ G. Reid, Practical Sanitation: A Handbook for Sanitary Inspectors and Others Interested in Sanitation, 7th rev. edn (London, 1900), 160-7; L. Herbert, The History of the Institute of Wastes Management, 1898-1998 (Warwick, 1998), 11, 21-2. 


\section{Municipal management: the rise of the 'destructor'}

Throughout most of the nineteenth century, nuisance removal and disease prevention legislation motivated local authorities to grapple with waste. In its survey of 50 urban centres, the Royal Commission into the State of Large Towns and Populous Districts (1844) recorded just one location where refuse was removed regularly from working-class alleys at the expense of local rates. Two other towns indicated that refuse was removed by scavengers, but just one of these noted that this was done regularly, and that scavengers were employed by the local government. ${ }^{25}$ The Public Health Act of 1875 made it incumbent upon local authorities in England and Wales to organize removal and disposal of waste. ${ }^{26}$ A survey of 85 towns at the end of the century recorded that 70 employed their own staff to collect refuse, 2 used a combination of contractors and publicly funded services and 13 relied entirely on contractors. Significantly, the regularity of service varied dramatically from partial daily collection to once every six months. ${ }^{27}$ At the close of the nineteenth century, a significant gap existed between legislative intentions and the reality of local waste management. Emergent public health and sanitary experts actively sought the most salubrious and efficient means of refuse disposal.

Prior to 1875 , if waste was collected at all, private contractors had often undertaken the task. There was a perceptible push for incineration after the shift to municipally organized waste collection. Although Mead and Co., dust contractors at Paddington, had made an unsuccessful attempt to burn refuse in a poorly ventilated closed furnace in 1870, the first operational incinerator was designed and patented by A. Fryer in 1876 and engineered by Manlove, Alliott and Co. Ltd of Nottingham. ${ }^{28}$ Fryer first developed his special furnace to dispose of crushed sugar cane from which the juice had been extracted, thus finding an engineer's solution to sweet rubbish. He adapted his new technology to all refuse and christened his invention a 'destructor'. Some experts objected to this name on the grounds that matter is indestructible, but the name stuck throughout the first great wave of enthusiasm for large municipal incinerators. As 'destructors', these furnaces seemed to promise the ultimate solution to the management of solid waste. Manlove, Alliott, and Co. installed refuse destructors at Manchester, Birmingham and Leeds in the same year that the Fryer destructor was patented. By 1912, there were in excess of 338 refuse incinerators in Britain and over 80 of them also generated electricity for local use..$^{29}$

${ }^{25}$ Appendix to First Report of the Commissioners for Enquiring into the State of Large Towns and Populous Districts (1844; repr. Dublin, 1970), 6-11.

26 A.S. Wohl, Endangered Lives: Public Health in Victorian Britain (London, 1983), 142-204.

27 Moore, Sanitary Engineering, 530.

28 Maxwell, Removal and Disposal of Town Refuse, 86-7.

${ }^{29}$ D.G. Tucker, 'Refuse destructors and their use for generating electricity: a century of development', Industrial Archaeology Review, 2 (1977), 5. 
Proponents of refuse destructors freely deployed the ideology of progress to support their case. Tipping, therefore, was a 'primitive' form of refuse disposal that was most suited to nomadic Neolithic hunters it was 'a miserable link with the insanitary past'. Tips were perceived as 'fever beds' and were denounced as repositories of disease. Speaking at the 1896 Dublin Congress of the Royal Institute of Public Health, E. Magennis proclaimed, 'We know that amongst the many evils attributed to insanitary sites are reckoned typhoid, cholera, yellow fever, dysentery, rheumatism, and the numerous respiratory diseases so common to our climate.' Similarly, Goodrich declared that the tipping of refuse was directly responsible for zymotic disease and diarrhoea. Wielding a mixture of filth and germ theory, and assorted forms of contagionism, sanitary engineers implored local authorities to abandon tipping and adopt burning before the visitation of an epidemic. After all, fire would permit the perfect destruction of 'contagia and virus'. 'There is', preached Goodrich, 'only one method of the final disposition for the whole of the waste, that is the great purifier - fire. ${ }^{30}$

Throughout the late nineteenth and early twentieth centuries, expert sanitary engineers were almost unanimous in their praise for destructors. The Sanitary Record and Journal of Sanitary and Municipal Engineering predicted that the destructor was 'destined sooner or later to become universally adopted by the cities and towns of every civilised community'. ${ }^{31}$ By 1898, J.H. Maxwell declared: 'for all towns, the destruction ... of refuse by cremation is at the present day regarded as being at once the most sanitary, efficient, and in many cases the only means of satisfactory disposal'. ${ }^{32}$ Experts condemned cities that simply accumulated huge heaps of noisome rubbish with the quip: 'Their offence is rank - it stinks to heaven.' Numerous medical officers of health (MOH) and sanitary engineers lauded the health benefits of burning rubbish. After all, in an era haunted by the spectres of filth and germs, tips and loose refuse were breeding grounds for disease and for vectors of disease, such as flies and rats.

Like some Kafkaesque 'remarkable piece of apparatus', the destructor seemed to succumb to the logic of its name. ${ }^{33}$ For the year 1885-86, the Leeds' destructors consumed 35,248 tons of house and trade refuse. In addition, they burned:

Eleven cows, 3 calves, 17 sheep, 4 goats, 298 pigs, 5 turkeys, 2 carcasses of beef, 28 quarters of beef, $9 \mathrm{cwt}$ of pork, $10 \mathrm{cwt}$ of pickled tongues, $12 \mathrm{cwt}$ of herrings,

${ }^{30}$ Goodrich, Economic Disposal of Town's Refuse, 19, 7, 8, 18; and T. Codrington, Report on the Destruction of Town Refuse (London, 1888), 41.

31 'The refuse destructor: a modern necessity', The Sanitary Record and Journal of Sanitary and Municipal Engineering, 17 Nov. 1899, 440.

32 Maxwell, Removal and Disposal of Town Refuse, 65.

${ }^{33}$ See F. Kafka, 'In the penal colony [1914]', in C. Fadiman (ed.), The World of the Short Story: A Twentieth Century Collection (Boston, 1986), 51-71. 
218 cwt of shellfish, 1 cwt of sugar, 285 dogs, 109 cats, 13 foxes, 1 sea serpent, 147 mattresses, beds, pillows, and bolsters, 7 blankets, quilts and sheets, 36 pieces of carpet, 7 hearth rugs and mats, 33 pieces of wearing apparel, 1 bedstead, 1 sofa, 1 chair, and 1 bundle of rags.

Destructors fulfilled their function as great purifiers, and were employed to destroy diseased animals and materials and condemned food. After an outbreak of swine fever, the same works destroyed 200 pigs, with the report of 'only a faint odour of roast pork being perceptible on a hill to leeward of the chimney'. ${ }^{34}$ The Salford destructor incorporated animal cremation into its multi-functionality. The main works included an area for housing stray dogs, which, if not claimed, were 'caged, drowned in the canal, and cremated in the cells'. ${ }^{35}$ The destructor, as a tool of waste disposal, seemed to possess an unquenchable appetite at a time when Britain confronted the challenges posed by clearly defined waste streams.

\section{Waste and social marginalization}

Technology was not, however, the only factor that shaped the application of municipal destructors. The social geography of cities played a significant role in waste disposal. Recent studies of environmental justice in the United States have found that incinerators are disproportionately overrepresented in areas populated by socially marginalized groups. ${ }^{36}$ In their efforts to convince people of the benign effects of destructors, nineteenthcentury engineers boasted about the close proximity of many of the works to residential homes. T. Codrington noted that the destructor in Whitechapel, London, was located in a densely populated neighbourhood, and that the brickwork of the furnace cells was within a foot of the walls of the adjacent houses. ${ }^{37}$ As an impoverished area of the metropolis, Whitechapel was, perhaps, an unsurprising location for a destructor.

Other authors, however, took pains to indicate that destructors were located near 'high-class property': one at Monte Carlo was near the entrance to the Royal Palace; and the one at Gloucester was within a stone's throw of the residence of the dean and the cathedral. At Sheerness, the plant was within eight feet of the local school and municipal offices. ${ }^{38}$ But the very fact that these engineers took explicit pains to link destructors to 'highclass property' raises a suspicion that Gloucester and Monte Carlo were great exceptions to the general rule. Moreover, it highlights the significance

${ }^{34}$ Codrington, Report on the Destruction of Town Refuse, 13. In addition, see Goodrich, Economic Disposal of Town's Refuse, 104-5.

35 Goodrich, Economic Disposal of Town's Refuse, 110.

36 See D.N. Pellow, Garbage Wars: The Struggle for Environmental Justice in Chicago (Cambridge, MA, 2002).

37 Codrington, Report on the Destruction of Town Refuse, 29. J.E. Cooney, 'The disposal of town refuse - cremation or utilisation', The Practitioner, 47 (1891), 304, repeats the same example of close proximity.

38 E.R. Matthews, Refuse Disposal: A Practical Manual (n.p., 1915), 37. 
of the cultural categories of high and low in relation to waste, hygiene, geographical space and social class. ${ }^{39}$

A piece published in Engineering made the relationship between social marginalization and destructors explicit:

Hoxton-Square was once a rural retreat, where rusticity and gentility went hand in hand. But that was very many years ago; probably beyond the memory of the very oldest inhabitant, for longevity is not a characteristic of modern Hoxton ... For generations it has been given up to squalor and garret industries. Its pallid inhabitants - starved often for food, always for light and air, besotted by cheap gin or bad beer - too ignorant or too careless to help themselves, and no one helping them, have sunk deeper into slough which lies below the foundations of our incomplete civilisation. The exceptionally large proportion of public-houses, where at present much gas is burnt, is put forward as one of the chief promises of success for the new electric light scheme. ${ }^{40}$

Launched by Lord Kelvin (W. Thomson), the proposed scheme for 'refuse and light' was declared evidence of the positive good arising from the new spirit of municipal patriotism. Wallowing in darkness and sloth, HoxtonSquare would be pulled to light and industry through the construction of a refuse destructor. The destructor promised order, morality and civilization. ${ }^{41}$

A. Jephson, vicar of St John's, was less inclined to see the benefits when a destructor was proposed for Lambeth in 1892. Lambeth already had one destructor that emitted sickening smells and huge quantities of ash. After pondering the question as to why this area of London had been chosen to receive vast amounts of refuse, he concluded: 'There is a population of 30,000 in this central part of London without one single wealthy resident with leisure time, and there is not one private family of influence, and the vestries think that they can do as they please. ${ }^{\prime 42}$

The emergence of destructors in late nineteenth-century Britain was not an uncontested triumph for sanitary engineering. There are scattered accounts of opposition to both proposed and operating works. Built in 1877, Birmingham's destructor was one of the first. Located across a canal from the General Hospital, it generated sufficient complaints to shut down the plant. In what became a common pattern, the destructor was re-built to improve its performance, and re-opened 'without complaint from the hospital'. ${ }^{43}$ In Bath, complaints about the destructor (built 1895) grew so strong by the turn of the twentieth century that the council demanded

${ }^{39}$ For an explicit discussion of this point, see P. Stallybrass and A. White, The Politics and Poetics of Transgression (Ithaca, NY, 1986), especially 125-48.

40 'Refuse and light', Engineering, 2 Jul. 1897, 19-20 (19).

${ }^{41}$ For similar rhetoric in relation to New York's street cleansing department, see D.E. Burnstein, 'Progressivism and the urban crisis: the New York City garbage workers' strike of 1907', Journal of Urban History, 16 (1990), 386-423 (400-1).

42 A.W. Jephson, 'A cry from North Lambeth', Times, 4 Aug. 1887, 11.

43 Codrington, Report on the Destruction of Town Refuse, 7-8; and Goodrich, Economic Disposal of Town's Refuse, 100. 
the engineering firm correct the nuisance. The council of Scarborough was determined to remove the tips that blighted their seaside resort, but the destructor met with such fierce opposition that the plans for its construction had to be scrapped. ${ }^{44}$ J.E. Cooney, MOH for Fulham, cautioned readers of The Practitioner:

The suggestion of establishing a destructor in a parish sets all ratepayers up in arms, and gives rise to an outcry that cannot be resisted. In theory the incineration of refuse is beautiful, and it can be carried out fairly well in practice... Much of the evil may be due to carelessness or want of management, but whatever may be the cause, the destructor has earned for itself a bad name with the public, and it is almost impossible to establish one within the precincts of a parish. ${ }^{45}$

A decade later, in 1904, engineer D.J. Ross advised the City of London that inevitable legal proceedings rendered the use of destructors an impracticable solution to refuse disposal, despite its sanitary superiority over alternative methods. ${ }^{46}$ The introduction of the destructor highlighted tensions between technocratic experts and local residents when municipalities confronted organized waste disposal in the late nineteenth century. Perhaps nowhere is this better illustrated than Torquay.

\section{Torquay confronts its waste}

Urban growth and urbanization made it increasingly difficult to find suitable land for tipping. Consequently, in the late nineteenth century, Britain embraced municipal refuse incineration more enthusiastically than the USA because inexpensive, undeveloped land was less plentiful, and fuel and transportation costs were high. ${ }^{47}$ Although the increasing size and number of urban places were concentrated in the industrial North, Torquay was one of a number of south coast leisure, retirement and residential towns to experience growth. Its population was approximately 26,000 by the turn of the twentieth century. ${ }^{48}$ Like many of the rapidly expanding urban industrial centres in the Midlands and the North, Torquay opted for the construction of a refuse destructor in the last decade of the nineteenth century. Local opposition resulted in a relatively unique and well-documented investigation into Torquay's destructor. As a borough of moderate size, Torquay provides useful historical insight into waste management.

A petition signed by 70 residents of Torquay was submitted to The Lancet in 1902. Convinced that their health had been 'injuriously affected by the smoke fumes and gases ejected from the [local] refuse destructor', they

${ }^{44}$ Goodrich, Economic Disposal of Town's Refuse, 112, 14.

${ }^{45}$ Cooney, 'The disposal of town refuse', 305-6.

46 'Refuse disposal problems', 346.

47 Melosi, Garbage in the Cities, 170-2.

48 R.J. Morris, 'Urbanization', in J. Langton and R.J. Morris (eds.), Atlas of Industrializing Britain 1780-1914 (London, 1986), 164. 
requested the respected medical journal to send a 'commission to inquire into the matters so vitally affecting the health of Torquay and to point out what measures must be taken to safeguard the purity of the air'. ${ }^{49}$ The resultant report sheds considerable light on the social, economic and intellectual factors surrounding the 'refuse revolution' of late nineteenthand early twentieth-century Britain. But the Torquay incident is insightful because it adds considerable complexity to the triumphal contemporary accounts of the successes of progressive science and technology. Lurking just below the surface of these accounts of sanitary progress, there is evidence of opposition to the introduction of 'destructors'. With more attention to local contexts, these narratives of opposition reveal a great deal about attitudes towards waste, its management, the environment, pollution and public health.

\section{Forced to reconsider municipal waste management}

Prior to 1895, Torquay's refuse had been carted to several different tips, the principal one being north of the town just beyond the then borough boundaries at Windmill Hill. There were also tips near the Torquay General Hospital, and just south-east of the town limits. The refuse at the latter location was available to local residents if they wished to use it for garden manure, but they had to sort out the hard materials themselves. In general, the disposal of Torquay's waste prior to 1895 relied upon a relatively uncoordinated system of dumping. ${ }^{50}$ Subsequently, Torquay had to reconsider its methods of refuse disposal. Plans for the construction of an isolation hospital in close proximity to the town's principal tip at Windmill Hill forced the council to cease rubbish disposal in this location.

Moreover, the threat of a nuisance action by the Marychurch Urban District Council forced the Torquay council to find a suitable method of disposal for the 10,000 cartloads of festering refuse at the Windmill Hill site. After an unsuccessful appeal to farmers to cart the refuse away as manure, the council was fortunate to receive an offer from the owner of a brickfield clay-pit. ${ }^{51}$ Torquay had relatively well-defined waste streams that kept street sweepings, which were acknowledged as 'a marketable commodity', clearly distinct from household and trade refuse. ${ }^{52}$ Similarly, there was little chance of human excrement being mixed with household refuse. By the 1890s, Torquay had an operational sewage system that had been designed by Sir J. Bazalgette and constructed at a cost of $£ 100,000 .^{53}$

49 'The destructor nuisance at Torquay', The Lancet, 1 (25 Jan. 1902), 262.

50 Ibid., 262; 'Torquay's refuse destructor', The Torquay Directory and South Devon Journal, 29 Jan. 1902, 6.

51 'The destructor nuisance at Torquay', 263; 'Torquay's refuse destructor', 6.

52 'Torquay town council. The refuse destructor - Preb Wolfe criticised', The Torquay Times and South Devon Advertiser, 7 Sep. 1900, 2.

53 See 'Torquay boundary question. Proposed inclusion of St Marychurch \& Cockington. Local Government Inquiry', The Torquay Times and South Devon Advertiser, 2 Feb. 1900, 2. 
As a coastal town, Torquay might have considered dumping its rubbish at sea. This method of disposal faced increasing criticism by the time that the borough confronted its refuse dilemma.

Although general public health concerns were raised, the Torquay council was principally motivated to act through fear of a possible common law injunction that their refuse be designated a nuisance. Logistical and related economic considerations followed. In particular, the council considered availability and price of land, and relative haulage costs for tipping. ${ }^{54}$ In a nation where well over 50 per cent of the population lived in urban areas, these factors formed significant constituents in arguments surrounding the abandonment of tipping and the adoption of destructors. By reducing the distance which the refuse had to be carted, transportation costs could be cut. The land for a centrally located destructor, however, might still be expensive. ${ }^{55}$ With this in mind, the Local Government Board granted 30 year loans for these municipal projects. The Torquay town council obtained a loan of $£ 6,500$ to build a destructor.

\section{Disposal by fire}

After they had exhausted available space at a brickfield clay-pit, the Torquay town council decided that disposal by fire was the only viable option to abate the nuisance caused by the town's accumulating refuse. In keeping with what had become standard practice, three to four years elapsed before Torquay realized its goal of an operational destructor. ${ }^{56}$ Administratively, the background investigation and subsequent negotiations were undertaken by a sub-committee of the Roads Committee (subsequently the Destructor Committee), with the guidance of the borough surveyor. They reported the results of their initial investigations to the town council in June 1894, and submitted an eightpoint scheme to deploy a refuse destructor. ${ }^{57}$ Two years later, the Local Government Board sanctioned a loan for the purchase of land at Upton, and the council accepted the tender of Messrs Goddard, Massey and Warner of Nottingham to build a Warner destructor (patented 1888) ${ }^{58} \mathrm{~A}$ further

For Bazalgette's contribution to sanitary engineering, see S. Halliday, The Great Stink of London (London, 1999).

54 'Torquay town council', The Torquay Directory and South Devon Journal, 7 Oct. 1896, 5; 'Torquay town council', ibid., 8 Feb. 1899, 3; and 'The destructor nuisance at Torquay', 262-3.

55 H.S. Watson, Town Scavenging and Refuse Disposal (London, 1911), 34.

56 M.V. Melosi, 'Technology diffusion and refuse disposal: the case of the British destructor', in J.A. Tarr and G. Dupuy (eds.), Technology and the Rise of the Networked City in Europe and America (Philadelphia, 1988), 211. Torquay continued to tip rubbish at the Windmill Hill site until 1897, and formally ended its tenancy and all liability in May 1899. See: 'Torquay boundary question', 2; and 'Town council meeting, Wed 2 May 1899. End of refuse tip', The Torquay Directory and South Devon Journal, 3 May 1899.

57 Torquay Borough Council Minutes, Devon Record Office, TUDCM R4562A add 2/TC10, 5 Jun. $1895,378$.

58 TUDCM R4562A add 2/TC10, 7 Jul. 1896, 6 Oct. 1896, and 1 Dec. 1896, 656, 695, 20. 
loan from the Local Government Board permitted construction to begin in mid-1897.59

At a planning meeting, Torquay's town clerk had assured residents that the destructor would cause no nuisance. This assurance proved premature. Almost one year after the Torquay destructor first began operation, H.A. Garrett, the borough surveyor and engineer, gave an account of it to the Plymouth Meeting of the Institution of Mechanical Engineers. ${ }^{60}$ Perhaps unsurprisingly, he offered a narrative of an unqualified success, with no mention of any opposition. His technical account, however, contained details that might raise concerns for fellow sanitary engineers.

Garrett began by deferring to the expertise of Lord Kelvin, who, with the assistance of A. Barr, had produced a report in March 1899 that strongly endorsed refuse destructors as virtually smoke-free. After summarizing Kelvin's report on the destruction and utilization of waste, The Times was moved to declare that our public bodies have no longer any excuse for referring to "waste products", but have within their reach the means of turning the most unpromising kinds of refuse to a highly profitable account ${ }^{\prime}{ }^{61}$ In a similar vein, Garrett described the combination of destruction and utilization in which the Torquay plant was engaged. The destructor included two multitubular boilers that supplied steam for two engines, which drove a mortar mill, a clinker mill and a dynamo. The latter produced lighting for the works and for the immediate vicinity. In addition, one of the engines drove a high-pressure fan that forced foul air from the refuse on the tipping platform across the fire. The mortar, clinker, ashes and flue dust were sold to local builders. And it was hoped that by adding carbolic acid to the flue dust, they could produce a disinfectant powder for offensive ashpits and boxes. Like alkali works, the destructor's public health status was slightly ambiguous: it could lay claim to positive sanitary contributions while belching forth noxious gases. ${ }^{62}$

As part of his statistical evidence, Garrett supplied information on Torquay's refuse composition in December/ January 1898/99:63

Paper, cardboard boxes, straw, packing material $12.29 \%$

Vegetable and garden refuse impregnated with fine ash $52.072 \%$

Screenings, cinders, clinkers, pieces of small coal

$6.51 \%$

59 TUDCM R4562A add 2/TC10, 6 Apr. 1897, 6 Jul. 1897, 77, 111. For Local Government Board loans, see C. Bellamy, Administering Central-Local Relations, 1871-1919: The Local Government Board in its Fiscal and Cultural Context (Manchester, 1988), 79-107. See especially 93-4 for the context of the 1890s.

60 H.A. Garrett, 'Refuse disposal', Engineering, 18 Aug. 1899, 215-16.

61 'Lord Kelvin on refuse destruction', Times, 31 Mar. 1899, 7.

62 See Wohl, Endangered Lives, 206.

63 Garrett, 'Refuse disposal', 216. 
Fine ashes and dust

Pots, pans, crockery, bottles

$3.172 \%$

Rags, bones

$0.3506 \%$

Refuse composition varied between localities and nations. For most large British cities with destructors, the single greatest component of household refuse was cinder or breeze, and ash.

Sanitary engineers contended that Britain led the world in the adoption of destructors because the nation's refuse had a high cinder and ash content and, therefore, a high calorific value. Moreover, households located close to coalfields would obtain coal more cheaply, and would, therefore, be less frugal in disposing of cinders. On this basis, Goodrich mapped the relationship between the emergence of destructors and the location of British coalfields. ${ }^{64}$ In contrast, Americans had a lower cinder and ash content and often a higher organic one. Consequently, their destructors often required coal assistance. With its high organic content, Torquay's destructor would have struggled to burn efficiently. And, as engineers observed, a seaside resort would experience a greater than usual variation in refuse quantity and composition between summer and winter months. ${ }^{65}$ In general, however, refuse should have contained higher cinder content in the winter than in the summer.

In the months following his paper, a number of engineers questioned Garrett's competence and the efficiency of the Torquay destructor. ${ }^{66}$ Most noted that the reported steam pressure varied between 38 and 105 pounds per square inch. For the plant to generate electricity properly, it would require a steady and regular supply of steam. Torquay's fluctuations were assessed as 'simply intolerable'. And, as one critic observed, producing steam pressure of 105 pounds per square inch in a boiler only designed for 80 represented endangerment of life. Garrett had claimed in his paper that low temperatures were best for the destruction of refuse. He also informed his audience that the Torquay destructor was equipped with an oil jet cremator to burn off any excess smoke. He proudly reported that the latter had never needed to be used. By the end of the nineteenth century, the best contemporary evidence had proved that constant high temperatures were essential for the reduction of smoke and fumes. ${ }^{67}$ Garrett's endorsement of low-temperature burning, his report of tremendous fluctuation in steam pressure and his omission of any temperature data did not bode well for the proper functioning of the destructor. One critic concluded that the

${ }^{64}$ Goodrich, Economic Disposal of Town's Refuse, 29-33.

65 Matthews, Refuse Disposal, 31-3.

66 M.B. Dongosh, 'Refuse disposal: to the editor of Engineering', Engineering, 25 Aug. 1899, 243; and Goodrich, Economic Disposal of Town's Refuse, 65-7.

67 'The designing and construction of refuse destructors', The Sanitary Record, 25 Nov. 1898, 560; F. Watson, 'Dust destruction: an expert's view', Municipal Journal, 8 Apr. 1904, 284; and Melosi, 'Technology diffusion and refuse disposal', 210. 
failure to use the oil-jet cremator seemed to indicate that there had not yet been any complaints.

\section{Destructive criticism}

Ignited for the first time in September 1898, the Torquay destructor began to elicit complaints from neighbouring residents one year later. Torquay's problems were compounded by an insufficient flow of waste. Consequently, in the absence of sufficient amounts of rubbish, the destructor was shut down for brief periods; on resumption, combustion was imperfect until temperatures rose. Similarly, Torquay's unusually high concentration of organic refuse in its waste stream burdened the destructor with wet matter that was difficult to burn. ${ }^{68}$ By 1900, opposition had gathered pace. Often enveloped in black, brown and pearl-grey smoke, people lodged a litany of health complaints: choking sensations; irritation of the throat; nausea; sore gums; headaches; abdominal pains; vomiting and general malaise. ${ }^{69}$ T. Codrington, in his Report on the Destruction of Town Refuse (1888) for the Local Government Board, observed that destructors could produce ash, smoke and vapours with offensive smells. Mr Rimington, the borough analyst of Bradford, attempted to capture these obnoxious vapours in alcohol, and produced, he claimed, something that 'when diluted, was in taste and smell not unlike Scotch whiskey $[\mathrm{sic}]]^{70} \mathrm{In}$ the form of gases, particulates and residual ash, incinerators can produce a toxic dram of pollution.

In the wake of the first wave of complaints of a nuisance in Torquay, one councillor enquired whether the unsatisfactory operation of the destructor could constitute a claim against the manufacturer. The chairman of the Destructor Committee exonerated the manufacturer: 'The difficulties which had arisen were not due to the destructor, but to the insufficiency and poverty of the refuse. ${ }^{71} \mathrm{C}$. Jones, a representative of the manufacturer, reiterated this assessment after he inspected the Torquay destructor at the paid behest of the town council. He concluded that the calorific value of Torquay's refuse had greatly decreased with the introduction of domestic gas stoves, and the resultant drop in coal ash and cinder. Furthermore, he noted the significant amount of 'garden stuff' in the waste stream, and he welcomed the potential increase in refuse to feed the destructor once the neighbouring urban districts of St Marychurch and Cockington were subsumed within the borough. ${ }^{72}$

68 'Town council meeting', The Torquay Directory and South Devon Journal, 3 Oct. 1900, 5.

69 'The destructor nuisance at Torquay', The Lancet, 1 (1 Feb. 1902), 335-6.

70 Codrington, Report on the Destruction of Town Refuse, 38-47 (38).

71 'Town council meeting, Tuesday 2 October 1900', The Torquay Directory and South Devon Journal, 3 Oct. 1900, 5.

72 'Torquay town council. The refuse destructor - Preb. Wolfe criticised', 2. Gas cooking had reached the working classes by the 1890 s. See P. Thorsheim, 'The paradox of smokeless 


\section{Destructor fuel, geopolitics and class}

The role of garden refuse in the Torquay destructor episode highlights some of the ambiguities surrounding this form of refuse disposal. Inevitably, noxious smoke arose from burning refuse, but in the nineteenth century this pollution could only be challenged through common law proceedings. Moreover, the complainant had to provide proof that harm came from a specific polluter. ${ }^{73}$

Unlike urban industrial centres in the North, the seaside health and leisure resort of Torquay should have provided fewer obvious polluters with which to conflate noxious smoke and gases. Located in the middle of an apple orchard in a valley, the destructor abutted a dense cluster of buildings on one side, and an active building site on another. Two tripeboilers, a slaughter-house and an iron foundry were all in close proximity. And four lime kilns were also relatively close. ${ }^{74}$ Consequently, the Torquay destructor enjoyed close proximity to some standard 'nuisance' trades. These, however, were not used to deflect blame for pollution. Home garden refuse fires were blamed for 'pestiferous nuisances', and a local by-law banning them was introduced in 1899, shortly after the destructor began operation. The by-law declared, 'No person shall set fire to or burn any garden or other refuse or rubbish in the Borough.' From 26 September 1899, the town council provided free removal of garden refuse. The Destructor Committee and the borough surveyor oversaw implementation and enforcement of the by-law. ${ }^{75}$ Undoubtedly, this seemed like a clever strategy. Blame could be deflected away from the destructor, and combustible material could be obtained to feed its undernourished fires. Unfortunately, this type of organic refuse had high water content and proved difficult to burn effectively. A steady stream of smoke nuisance complaints began within days of the introduction of free garden refuse removal. ${ }^{76}$

In the midst of the destructor controversy, the Torquay council made a successful bid to subsume the neighbouring urban districts of Cockington and St Marychurch within new borough boundaries. Ostensibly, a lack of suitable building land lay behind this action, but at the Local Government Inquiry, 'sanitary matters' played a significant role in the discussions. The legal representative for Torquay argued that the borough's status as a health resort required unity of provision of sanitary services. He poured praise on Torquay's water and sewage arrangements, and implicitly

fuels: gas, coke and the environment in Britain, 1813-1949', Environment and History, 8 (2002), 395.

73 D. Stradling and P. Thorsheim, 'The smoke of great cities: British and American efforts to control air pollution, 1860-1914', Environmental History, 4 (1999), 8.

74 'The destructor nuisance at Torquay', The Lancet, 1 (25 Jan. 1902), 263.

75 See 'Torquay garden refuse', The Torquay Directory and South Devon Journal, 9 Jan. 1901; Torquay Borough Council Minutes, TBCM R4582 A/TC2, 13 Dec. 1900.

76 See, for instance: TUDCM R4562A add 2/TC10, 3 Oct. 1899; TBCM R4582 A/TC1, 14 Nov. 1899 . 
offered the refuse destructor as one element in the borough's healthful sanitary arrangements. In contrast, he observed that the agricultural district of St Marychurch distributed its refuse among farmers. He denounced the resultant 'tin pots and refuse in front of some of the cottages' as 'not only an unmitigated nuisance, but a public danger'. The town clerk and the borough surveyor reinforced these points in their statements to the inquiry.

Moreover, the surveyor indicated that the Torquay destructor was capable of consuming the rubbish from Cockington and St Marychurch. ${ }^{77}$ Torquay increased its population by a further 10,000 rubbish-producing persons at a time when its destructor struggled to operate efficiently for want of sufficient rubbish. On 6 November 1900, St Marychurch, Babbacombe and Cockington were amalgamated with Torquay by an act of parliament. ${ }^{78}$ In February of the following year, the borough council resolved that 'no house refuse be sold or deposited... in any part of the Borough for tillage purposes but that all such refuse be taken to the Destructor for cremation'. ${ }^{79}$ The edacious appetite of the destructor significantly shaped sanitary policy and the geopolitical landscape of the borough.

Similarly, the social landscape played a significant role in the destructor's siting, and subsequent opposition to its operation. The initial proposal to locate the destructor in Upton elicited minor dissent in the town council and a petition of opposition from 50 affected residents. ${ }^{80}$ Councillor Glanfield objected that the proposed site was 'in the heart of a large working-class population' ${ }^{\prime 1}{ }^{8}$ His attempt to relocate the destructor to a brickfield on the outskirts of the town was defeated by a vote of approximately three to one. A correspondent to one of the local newspapers detected clear class prejudice: 'Had the Warberries been the place selected for the destructor we should, I fancy, have heard immediately a powerful protest from our villa residents. Why, then, should the poor be obliged to bear what the rich would not for a moment tolerate?'82 Echoing this sentiment, 'Another Uptonite' observed that a site had been chosen where 'many [residents] are too poor to move away'. ${ }^{.3}$

77 See 'Torquay boundary question', 2, 8. Goodrich, Economic Disposal of Town's Refuse, 4, predicted that the 'time must surely come when, in choosing a health-resort, the choice will fall on sanitary health-resorts - where sewage is dealt with in a modern manner and refuse destroyed by fire'.

78 See 'Torquay in the nineteenth century. Notable events in the century', The Torquay Directory and South Devon Journal, 9 Jan. 1901, 3.

79 Torquay Borough Council Minutes, TBCM R4582 A/TC2, 14 Feb. 1901.

80 TUDCM R4562A add 2/TC10, 6 Oct. 1896, 5 Jan. 1897, 695, 27.

81 'Torquay town council', The Torquay Directory and South Devon Journal, 7 Oct. 1896, 5.

82 An Uptonite, 'Late correspondence. The refuse destructor', The Torquay Directory and South Devon Journal, 14 Oct. 1896, 5.

83 Another Uptonite, 'Correspondence. The refuse destructor', The Torquay Directory and South Devon Journal, 21 Oct. 1896, 3. For interesting parallels with gasworks, see Thorsheim, 'The paradox of smokeless fuels', 386-90. 
Perhaps unsurprisingly, the most vocal complaints against the operational destructor did not arise from the poor residents of Upton valley, but from the residents of the valuable property - the villas - on the hills surrounding the destructor. Dr H. Humphreys, one such resident, was instrumental in organizing the petition to The Lancet. Incidental details reveal the socio-economic status of his fellow petitioners. Mr and Mrs Hill, for instance, were routinely forced to retreat to their yacht because the fumes had become unbearable. ${ }^{84}$ In Torquay, topography had conspired against the usually 'safe' spatial relationship between destructors and social class.

\section{The expert engineer: managing waste, public health and pollution}

Despite the centrality of issues of pollution and public health, the $\mathrm{MOH}$ played no significant role in the destructor debates. On just one occasion, on 12 July 1900, he presented to the town council a complaint that he had received of an 'annoyance caused by smell from the destructor' ${ }^{8}{ }^{85}$ The sanitary inspectors were also notably absent from discussions. They were mentioned only once, and this was in support of the destructor: 'our sanitary inspectors, although living within 300 yards, had never been able to detect any smell' ${ }^{86}$

Non-governmental medical men played a role in opposing the nuisance. Dr H. Humphreys, a local resident and a Member of the Royal College of Physicians, was one of the most active opponents. Similarly, Dr Winter and Dr S. Grose lodged complaints against the destructor and its management; and, of course, The Lancet entered the fray ${ }^{87}$ Throughout the nineteenth century, The Lancet allied itself to the cause of smoke abatement. ${ }^{88}$ Undoubtedly, it was knowledge of these allegiances that prompted the Manchester-based Chemical Trade Journal to denounce The Lancet's Torquay destructor investigation as '[o]ne of the most amusing articles on technical subjects it has ever been our lot to peruse... [I]t is based upon misconceptions and absolute ignorance of the principles upon which successful destructors work. ${ }^{89}$

In general, the clash between the Chemical Trade Journal and The Lancet was symptomatic of the technical division of labour surrounding assessments of destructors as smoke nuisances. Refuse destructors were

\footnotetext{
84 'The destructor nuisance at Torquay', 335-6; 'Torquay town council', The Torquay Directory and South Devon Journal, 4 Jun. 1902, 5; and H. Humphreys, 'Correspondence. The refuse destructor', ibid., 11 Jun. 1902, 3.

85 Torquay Borough Council Minutes, TBCM R4582A/TC1, 12 Jul. 1900.

86 Truth, 'Letters', The Torquay Times and South Devon Advertiser, 3 Jul. 1900, p. 3.

${ }^{87}$ For Winter's participation, see TBCM R4582A/TC1, 16 Aug. 1900; and see S. Grose MD, 'Letters. The refuse destructor', The Torquay Times and South Devon Advertiser, 27 Jul. 1900, p. 3.

88 Stradling and Thorsheim, 'The smoke of great cities', 19.

89 'Should the cobbler stick to his last?', Chemical Trade Journal, 30 (22 Feb. 1902), 171-2.
} 
the province of engineers and specialist committees of local government. At Woolwich, the engines of the new refuse destructor (1903) were named 'Flavia', 'Wilhemina', 'Gertrude' and 'Muriel' after the names of the wives of the engineer and the Electricity Committee. ${ }^{90}$ This intimate relationship was maintained when destructors faced serious scrutiny. Alleged nuisances were most often treated as technical problems that required adjustments in the technology or its management. A complaint of nuisance, signed by 46 ratepayers of the borough, and a letter of complaint from the St Marychurch urban district council forced the Torquay town council to take action. After paid consultation with C. Jones, the council elected to install a coke cremator to enhance combustion. The mayor proudly proclaimed that the cremator 'would destroy the last germ of every reasonable complaint', and one month later he responded to threat of legal action, by Mr D.P. Chatto of St Marychurch, by acknowledging the work-in-progress on this technological fix. ${ }^{91}$

Significantly, the Torquay town council only took steps to abate the nuisance in the wake of a threat of legal action from the neighbouring urban district. Throughout the nineteenth century, local government was responsible for enforcement of nuisance laws. Often this entailed a conflict of interest because owners of large polluting factories, mines or chemical works held influential positions in local government. ${ }^{92}$ Like many gasworks, the case of refuse destructors was even more overtly problematic; these works were municipally owned and operated. ${ }^{93}$ S. Grose noted the dilemma that faced persons who opposed Torquay's 'stink distiller': 'The fumes from the "Destructor" constitute a legal nuisance, and if "uttered" by a townsmen instead of by a Town Council would be speedily stopped by the long arm of the law. ${ }^{\prime 94}$ Moreover, if a complainant wished to take the matter beyond the town council, their next port of call would be the Local Government Board. The latter body had provided long-term loans for the construction of destructors and, therefore, had a financial interest in their survival.

At a time when people increasingly anticipated governmental intervention to ensure acceptable standards of public health, smoke pollution remained notoriously difficult to police. Arguably, the Alkali Acts (first passed 1863) were the one success story in this field. ${ }^{95}$ Consequently, when the coke cremator failed to alleviate the problems at Torquay and the threat of legal action lingered, the town council requested Manchester chemist G. Davis, former alkali inspector of the

${ }^{90}$ M. Mills, 'Electricity from household waste in Edwardian Woolwich', Bygone Kent, 21 (2000), 541.

91 'Town council. The refuse destructor', The Torquay Directory and South Devon Journal, 5 Sep. 1900, 5; and TBCM R4582A/TC1, 11 Oct. 1900.

92 Stradling and Thorsheim, 'The smoke of great cities', 18.

93 Thorsheim, 'The paradox of smokeless fuels', 394.

${ }_{94}$ Grose, 'Letters', 3.

95 See Wohl, Endangered Lives, 205-32. 
Local Government Board, to examine the destructor and to make a written report. Davis identified the lack of consistently high temperatures as the principal problem at Torquay. On his recommendation, the coke cremator was replaced by a combustion chamber with 'baffling walls' to increase the temperature of escaping gases and to reduce the quantity of 'grit' reaching the chimney. ${ }^{96}$ Although Dr Humphreys wished to read Davis' initial report, the council denied this request for fear of legal action. Clearly, they believed that the report might be used to prove incompetent management of the destructor, so they never made its contents public.

Like the alkali industry, rarely did critics attack the inherent dangers of refuse incineration. Technological failure or human error was most often identified as the culprit. ${ }^{97}$ Although the town council implemented a number of operational and technological changes to the destructor, complainants suggested further technological fixes rather than demanding alternative forms of refuse disposal. Dr Humphreys, after two years of complaining, suggested 'one remedy, and one remedy only': to build a chimney that easily exceeded the height of the surrounding hills. ${ }^{98}$

Similarly, The Lancet's special sanitary commissioner concluded that Torquay was a unique and instructional case. The town council's gravest error had been to situate the destructor in a valley. Economic and aesthetic considerations lay behind this decision. A hill-top location would have impeded cartage of refuse and increased transport costs. In addition, it would have obstructed the view that was so important to a seaside resort. But a valley location meant that the top of the chimney was level with surrounding homes. Again, economic considerations compounded this difficulty. Although originally planned to be 220 feet high, the Torquay Destructor Committee elected to reduce this to 150 feet to save $£ 500$ in construction costs. Generally, The Lancet observed, the construction of tall chimneys made it impossible to gauge the impact of destructors: to determine whether combustion was perfect and fumes innocuous. ${ }^{99}$

Throughout history, 'the search for the ultimate sink' often led municipalities to construct ever-higher chimneys to diffuse pollution rather than to confront it. Technology, they believed, could transport the

96 See 'Town council meeting, 7 Jan. 1902', The Torquay Directory and South Devon Journal, 8 Jan. 1902, 5; TBCM R4582 A/TC3, 10 Apr. 1902, 15 May 1902; and 'Town council meeting, 3 June 1902', The Torquay Directory and South Devon Journal, 4 Jun. 1902, 5.

97 See Wohl, Endangered Lives, 226.

${ }^{98}$ Humphreys, 'The refuse destructor', 3.

99 'The destructor nuisance at Torquay', The Lancet, 1 (8 Feb. 1902), 404; and 'Town council meeting', The Torquay Directory and South Devon Journal, 3 Oct. 1900, 5. When the special sub-committee first formulated its eight-point plan for a destructor, the following was resolved: "That the Chimney shaft should be carried to a height of not less than 220 feet, so that its top may be at least 25 feet above any hill surrounding the suggested site. This recommendation is made in order to reduce any possible complaint being made by owners and occupiers of the surrounding property.' See TUDCM R4562A add 2/TC10, 5 Jun. 1894. 
stink directly to heaven. ${ }^{100}$ Torquay's residents had accidentally provided the exception to the rule, and, according to The Lancet, gifted science with a unique experiment. In an ambiguous conclusion, the sanitary commissioner contended that the results of this experiment would be of interest to every town and large city as they struggled to deal with their refuse problems. Several months later, The Torquay Directory issued a 'Pictorial' that claimed a pre-eminent position for the borough in sanitary science:

Nothing that science, skill, and money can achieve has been left undone... The local authorities and sanitary staff are imbued with a deep sense of the importance of perfect sanitary arrangements and devote no little time, energy, skill, and constant supervision to maintain in a high state of efficiency everything bearing upon, or contributing to, the health of the people. ${ }^{101}$

The previous year, the same local newspaper had listed the construction of the refuse destructor at Upton as a 'notable event of the century' in Torquay. ${ }^{102}$

Local opposition to the Torquay destructor flickered - rather than flamed - out. Residents lodged multiple complaints throughout 1902, the year of The Lancet's special investigation, but these subsided in the years that followed. According to the Borough Council Minutes, the final complaint was received in January 1904. Like the previous year, it would be the only complaint to be received over the next 12 months, and the borough surveyor dismissed it as indeterminate 'after careful investigation' ${ }^{103}$ The council firmly believed that technological alterations to the destructor had solved problems with emissions. Undoubtedly, the geographical and demographic expansion of Torquay provided a more generous supply of fuel for the destructor. This, in turn, permitted the council to reduce its reliance on poor-burning organic garden refuse. Just one month after the amalgamation, the council restricted free removal of garden refuse to two loads per house, per annum. ${ }^{104}$ In combination with the technological alterations made at the suggestion of G. Davis, these measures probably provided constant high temperatures in the destructor cells, and some mitigation of the smoke nuisance. Decline in opposition, however, also marked the triumph of the refuse revolution.

100 J.A. Tarr, The Search for the Ultimate Sink: Urban Pollution in Historical Perspective (Akron, 1996), part III. In addition, see S. Mosley, The Chimney of the World: A History of Smoke Pollution in Victorian and Edwardian Manchester (Cambridge, 2001).

101 Quoted in 'The destructor nuisance at Torquay', The Lancet, 2 (12 Jul. 1902), 92.

102 'Torquay in the nineteenth century', 3.

103 TBCM R4582A/TC4, 5, 10 Sep. 1903 and 14 Jan. 1904.

104 TBCM R4582A/TC2, 13 Dec. 1900. 


\section{Conclusion}

The refuse revolution was a shift to municipal and professional management of waste in late nineteenth-century Britain. Pervasive concern for public health and hygiene convinced people that rubbish must be removed quickly and with finality. Experts argued that reuse and utilization of rubbish were ineffective and unhygienic methods of waste disposal. Purification by fire, they argued, was the most viable and efficient option. Progressive local authorities, therefore, embraced the emergent technology of destructors and thereby wed municipal waste management to large-scale and cost-ineffective waste disposal schemes. As capital-intensive projects, municipal destructors were technologies that followed a path dependent development trajectory: despite the evident technological and economic shortcomings of operational destructors, considerable inertia precluded their abandonment and the adoption of alternative methods. ${ }^{105}$ As T. Cooper has demonstrated, the political and economic crises engendered by total war led to brief rediscoveries of reuse, but, in the longer term, the exceptionalism of war failed to translate salvage into enduring peacetime recycling. ${ }^{106}$

Incinerators, however, never regained the popularity they enjoyed during the refuse revolution of 1870 to 1914 . Whereas there were in excess of 300 incinerators in Britain at the turn of the twentieth century, there were just 19100 years later. Although displaced by the rise of the 'sanitary landfill' by the 1930s, incinerator technology persisted as a viable alternative. In February 2006, the UK government launched a review of its waste strategy with a declaration that it intended to increase its rate of incineration of municipal waste from 9 per cent to 22 per cent. Increased incineration, the government argued, would reduce waste in landfill, and it would produce 'green energy' through waste-to-energy applications. Environmental groups immediately opposed the proposal on the grounds that it would reduce recycling. Friends of the Earth declared: 'Once built, incinerators lock councils in to supplying them with large amounts of waste that could be better recycled or composted.' Moreover, they asserted, it would expose local residents to increased health risks from the ensuing pollution. ${ }^{107}$

First introduced in the late nineteenth century, incineration remains the most contentious method of municipal waste disposal. Incinerators require initial high capital investment, and a skilled labour force to maintain them. Moreover, despite the pronouncements of nineteenth-century engineers,

105 See M. Melosi, 'Path dependence and urban history: is a marriage possible?', in Schott, Luckin and Massard-Guilbaud (eds.), Resources of the City, 262-75; and McGowan, 'American wasteland'.

106 T. Cooper, 'Challenging the refuse revolution: war, waste and the rediscovery of recycling', Historical Research (forthcoming, 2007).

107 See 'Review launched to tackle waste', BBC News: http://news.bbc.co.uk/go/pr/fr//1/hi/sci/tech/4708758.stm (accessed 17 Feb. 2006). 
incinerators displace pollution rather than obliterate waste. And energy recovered from the heterogeneous fuel of rubbish struggles to be economically competitive. Torquay's early destructor experience demonstrates that many of the difficulties and challenges of incineration were present from the inception of the technology. Opposition to the operational destructor demonstrated that the effort to remove one environmental problem might introduce another. Although recent debates on incineration have resonances of the past, they also introduce new complexities. Like the residents of Torquay earlier, twenty-first-century environmental activists object to the pollution and public health dangers arising from the incineration of rubbish. They, however, operate within a post-1960s environmentalist rubric that weds public health concerns to nature conservation and preservation in a global context. Whereas past discussions assessed the possible benefits arising from waste-to-energy, recent critics of incineration have complained that it detracts from the push for renewable energy sources. 